\title{
NOISE CHARACTERISTICS OF SEA WAVES BASED ON ITS HEIGHT, PERIOD AND BREAKING WAVES
}

\author{
Amron Amron ${ }^{1 *}$, Fiyesti Chandra Alam ${ }^{1}$, Mukti Trenggono ${ }^{13}$, Rizqi Rizaldi Hidayat ${ }^{13}$, \\ Maria Dyah Nur Meinita ${ }^{23}$ \\ ${ }^{1}$ Marine Science Department, Fisheries and Marine Science Faculty, Jenderal Soedirman University \\ J1. dr. Soeparno Kampus Unsoed Karangwangkal Purwokerto 53122 INDONESIA \\ ${ }^{2}$ Aquatic Resources Management Department, Fisheries and Marine Science Faculty, Jenderal Soedirman University \\ J1. dr. Soeparno Kampus Unsoed Karangwangkal Purwokerto 53122 INDONESIA \\ ${ }^{2}$ Centre for Maritime Bioscience, Institute for Research and Community Services Jenderal Soedirman University \\ Jl. dr. Soeparno Kampus Unsoed Karangwangkal Purwokerto 53122 INDONESIA \\ *email: amron@unsoed.ac.id
}

\begin{abstract}
ABSTRAK
Suara gelombang merupakan salah satu sumber ambient noise di perairan yang menyebabkan peran suara sebagai media transmisi informasi dan komunikasi menjadi terganggu. Karakteristik derau gelombang dapat dipengaruhi oleh parameter gelombang itu sendiri, seperti tinggi dan periode gelombang serta gelombang pecah. Penelitian ini bertujuan untuk mengetahui karakteristik derau (intensitas, frekuensi, durasi pulsa dan durasi interval) gelombang berdasarkan tinggi dan periode gelombang serta gelombang pecah. Akuisisi data suara gelombang menggunakan hidrofon, visual gelombang menggunakan kamera cctv dan parameter gelombang menggunakan ADCP. Karakteristik suara berdasarkan tinggi dan periode gelombang serta gelombang pecah dianalisis menggunakan analisis Kruskal Wallis. Intensitas noise dipengaruhi oleh semua parameter gelombang, sedangkan durasi pulsa hanya berubah secara signifikan berdasarkan perubahan tinggi dan periode gelombang serta cepat rambat gelombang pecah. Frekuensi noise hanya dipengaruhi oleh tinggi gelombang pecah. Karakteristik noise lainnya, durasi interval tidak signifikan dipengaruhi oleh semua parameter gelombang.
\end{abstract}

Kata Kunci: Intensitas, Frekuensi; Durasi Pulsa; Durasi Interval; Gelombang

\begin{abstract}
Wave sound is one of the sources of ambient noise in the waters which causes the role of sound as a transmission medium of information and communication becomes disrupted. The characteristics of wave noise can be influenced by their parameters, such as height and period of the waves and breaking waves. The study aimed to determine the characteristics of noise (intensity, frequency, pulse duration and interval duration) of waves based on its height, periods and breaking waves. Data acquisition for sound wave is obtained by hydrophones, visual of wave from CCTV cameras, and wave parameters is determined from ADCP data. Sound characteristics based its height, period and breaking waves were analyzed by Kruskal-Wallis analysis. The intensity of noise is affected by all wave parameters, while the pulse duration is significantly influenced by the changes in height and wave period, and the breaking waves velocity. Frequency of noise is only impacted by the breaking wave height. Other noise characteristics, the interval duration is not significantly influenced by all wave parameters.
\end{abstract}

Keywords: Intensity; Frequency; Pulse Duration; Interval Duration; Waves

\section{INTRODUCTION}

The role of sound in waters is very important as a transmission medium of information and communication because sound waves can propagate at greater distances in the water column (Simmonds and MacLenan, 2005). Water is an excellent medium for sound propagation because the molecules of water have a high-density level (Southall et al., 2007; Bradley and Stern, 2008; Slabbekoorn et al., 2010). The sources of sound in the waters come from anthropogenic activities (Hildebrand, 2009; Triwahyanti et al, 2018; Peng et al, 2016), aquatic biota (Kaatz 2002; Amron et al, 2017; Amron et al 2018) and physical processes in waters (Salinas and Amezquita, 2013; Barclay and Buckingham, 2013).

One of the physical processes as a source of sound with certain characteristics in the waters is the sound of ocean waves. Waves are the changes in the shape of the water surface that caused by the 
external forces and offset by gravitational forces, and due to surface tension (Umpel et al., 2015). In general, sea waves are caused by the wind, both directly or indirectly. Wave formation generally occurs in offshore areas and will move to long distances across the sea, with only a small loss of their energy (Wakkary, 2017). The process of waves propagation from offshore to coastal or shallow water will change in the form of refraction, diffraction, siltation, reflection and finally the wave will break (Chrismadhisti, 2014). The process of changing the shape will produce noise with certain characteristics.

The characteristics of wave noise in the sea are largely determined by the speed of the wind which is the main generator. The high frequency is produced from the sound spectrum has a close correlation with the single bubble oscillation trapped during the breaking wave process and can be theoretically modeled (Means and Heitmeyer, 2001). Bubbles are created by the breaking waves in the sea are concluded as a major factor in many diverse ocean processes including gas transfer, wind noise and surface foam coverage (Medwin and Daniel, 1990).

The mechanism of noise production of braking waves is produced by individual bubbles and bubble clouds entering during the breaking wave process (Kolaini and Crum, 1994). Breaking waves produce significant levels of noise with below 500 $\mathrm{Hz}$ (Lamarre and Melvillea, 1994). Kolaini and Crum (1994) stated that the source of noise from spilling type of the breaking waves is mostly caused by oscillations from a single bubble which has a low frequency of $400 \mathrm{~Hz}$. Plunging type of breaking waves produce noise with above $750 \mathrm{~Hz}$ and spilling types with $300 \mathrm{~Hz}$ (Means and Heitmeyer, 2001).

Investigation related to the characteristics of wave noise is still limited, so this research is important to do. In this study, the characteristics of wave noise that observed are frequency, intensity, pulse duration and interval duration. Wave noise characteristics can be influenced by its height, period and breaking waves.

\section{METHODS}

Observation method is used in this study by direct observation of waves noise in the Cilacap Waters (Central Java) on 17 - 20 April 2019. Data of wave noise is recorded by using a hydrophone where connected to the data processing software (Figure 1). Measurement of ocean wave parameters by using ADCP (Acoustic Doppler Current Profiler) which is mounted on the sea bed with the vertical beaming. Visualization of height and wave period and type of breaking wave by using CCTV camera which connected to the decoder and LCD monitor. Noise, visual and wave parameters are performed continuously and synchronized so that the observation time of the three methods is carried out simultaneously.

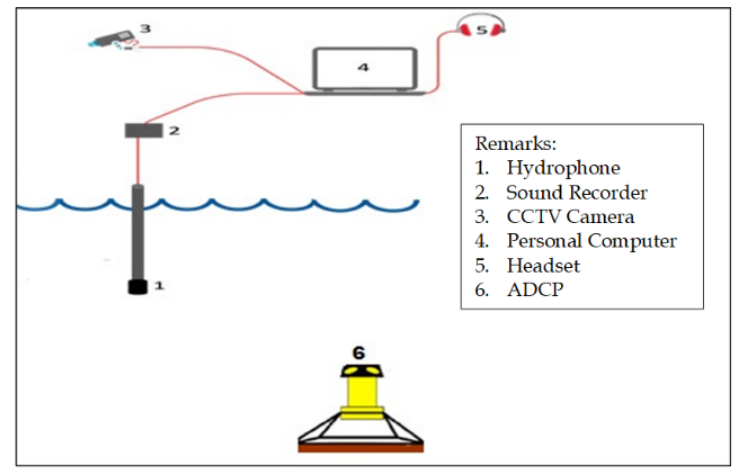

Figure 1. Observation Setup

Characteristics of noise (frequency, intensity, pulse duration and interval duration) is determined by envelope and spectrum analysis. Envelope analysis is performed by a low pass filter, which is passing high frequency of noise with assuming the desired sound is at a frequency below $1 \mathrm{kHz}$. From the results of the data processing obtained the intensity, frequency, pulse duration and interval duration. The intensity that obtained from the recording process using a hydrophone is the sound intensity in $\mathrm{W} / \mathrm{m}^{2}$ units. This value is then equalized in the form of intensity (pressure) to the unit $\mathrm{dB}$ re $\mu \mathrm{Pa}$. The initial step is to determine the value of intensity in units of $\mathrm{dB}$ re $\mathrm{W} / \mathrm{m}^{2}$ using the equation:

$$
\text { I dB re } \left.W / \mathrm{m}^{2}\right)=10 \log \frac{I\left(\mathrm{~W} / \mathrm{m}^{2}\right)}{1\left(\mathrm{~W} / \mathrm{m}^{2}\right)}
$$

The value of intensity is then converted to the form of pressure where according to Simmonds and MacLenan (2005) is:

where:

$$
P^{2}=I \times \rho \times C
$$

$\mathrm{P}$ : pressure $(\mathrm{Pa})$

I : intensity $(\mathrm{dB}$ re $\mathrm{W} / \mathrm{m} 2)$

P: sea density $(\mathrm{kg} / \mathrm{m} 3)$

$\mathrm{c}$ : sound speed $(\mathrm{m} / \mathrm{s})$

Because the unit is commonly used to express the sound, the pressure in $\mathrm{Pa}$ units is then changed to the unit $\mathrm{dB}$ re $\mu \mathrm{Pa}$ by using the equation:

$$
P_{(\text {dB re } \mu \mathrm{Pa})}=10 \log \frac{P_{(P a)}}{10_{(P a)}^{-6}}
$$

Another sound parameter which is the frequency of wave noise is processed by using spectrum analysis. Spectrum analysis will analyze 
the sound data in certain spectrums that determine frequencies based on the time domain.

The first step of data processing of the wave from the ADCP recording is pre-processing, such as orientation correction, local declination correction and error correction. Wave data in NetCDF (Network Common Data Format) with using MATLAB software is assisted by the ADCP toolbox to automatically check the orientation of the data. Declination correction is then performed to correct data due to the influence of the earth's magnetic field. While error correction consists of ensemble trimming and severely tilted ADCP. Ensemble trimming is the process of removing the ensemble at the end of the data while severely tilted ADCP is the process of correcting the ADCP bin error data due to the influence of aquatic benthic animals attached to the ADCP sensor (Cote et al., 2011).

The wave data from the ADCP acquisition that have been through pre-processing is in the term of wave height $(\mathrm{H})$ and wave period $(\mathrm{T})$. Next step is to determine the height of breaking wave $(\mathrm{Hb})$ and velocity of propagation the breaking wave propagation speed $(\mathrm{Cb})$ using the equation that developed by Triatmodjo (1999), which is:

$$
\begin{aligned}
& H_{0}^{\prime}=\frac{H}{K s} \\
& \frac{H_{b}}{H_{0}^{\prime}}=\frac{1}{3,3\left(\frac{H_{0}^{\prime}}{L_{0}}\right)^{1 / 3}} \\
& \frac{d_{b}}{H_{b}}=1,28 \\
& C_{b}=\sqrt{g \times d_{b}}
\end{aligned}
$$

Dackombe dan Gardiner (1983) determined the breaking wave coefficient (Bo) as

where:

$$
B_{0}=\frac{H_{0}}{L_{0} \operatorname{tg}^{2} \beta}
$$

$\mathrm{Ks} \quad$ : shoaling coefficient

$\mathrm{Hb}$ : breaking wave height (meter)

$\mathrm{db}$ : breaking wave depth (meter)

HO' : wave height in equivalent (meter)

HO : wave height (meter)

L0 : wave length (meter) $=1,56 \mathrm{X} \mathrm{T}$

$\mathrm{Cb}$ : velocity of breaking wave $(\mathrm{m} / \mathrm{det})$

g : acceleration due to gravity $\left(\mathrm{m} / \mathrm{s}^{2}\right)$

B0 : breaking wave coefficient

$\beta \quad$ : shore slope (degree)

Wave noise that have been obtained will processed by using Wavelab 6.1 software. Then analyzed to determine the characteristics of noise wave based on its height, period and breaking waves. The relationship between the high and velocity of propagation the breaking waves to the noise characteristics of broken wave based on the type is tested statistically by using Minitab 16 software.

The characteristics of the waves noise are analyzed descriptively by determining the mean and standard deviation of each sound parameter (intensity, frequency, pulse duration, and interval duration) based on the height, period and breaking wave. The difference in sound characteristics based on the height, period ang breaking waves is performed by using the Kruskal-Wallis test with a confidence level of 95\% (P-value <0.05).

\section{RESULTS AND DISCUSSION}

\section{Noise Characteristics of Sea Waves}

Characteristics of waves noise in Cilacap Waters were varies based on wave height (Table 1). Wave height $0.3-1.4 \mathrm{~m}$ can produce noise with a frequency of $335.40-475.50 \mathrm{~Hz}$, intensity 79.24 $86.99 \mathrm{~dB}$ re $\mu \mathrm{Pa}$, pulse duration $460.80-687.40 \mathrm{~ms}$ and interval duration 7,300.67 - 16,076.00 ms.

Table 1. Characteristics of wave noise based on wave height

\begin{tabular}{ccccc}
\hline $\begin{array}{c}\text { Height } \\
(\mathrm{m})\end{array}$ & $\begin{array}{c}\text { Frequency } \\
(\mathrm{Hz})\end{array}$ & $\begin{array}{c}\text { Intensity } \\
(\mathrm{dB} \text { re } \mu \mathrm{Pa})\end{array}$ & $\begin{array}{c}\text { Pulse } \\
\text { Duration } \\
(\mathrm{ms})\end{array}$ & $\begin{array}{c}\text { Interval } \\
\text { Duration } \\
(\mathrm{ms})\end{array}$ \\
\hline 0.3 & $384.00 \pm$ & $79.24 \pm$ & $687.40 \pm$ & $10,239.70 \pm$ \\
& 203.74 & 1.57 & 137.94 & $4,010.99$ \\
0.7 & $437.00 \pm$ & $84.15 \pm$ & $535.90 \pm$ & $7,893.20 \pm$ \\
& 158.75 & 1.40 & 81.86 & $6,744.03$ \\
0.8 & $342.80 \pm$ & $85.00 \pm$ & $650.27 \pm$ & $7,300.67 \pm$ \\
& 126.24 & 1.19 & 108.33 & $3,829.97$ \\
0.9 & $362.83 \pm$ & $85.24 \pm$ & $563.00 \pm$ & $16,076.00 \pm$ \\
& 122.05 & 1.50 & 83.04 & $9,150.79$ \\
1.0 & $464.04 \pm$ & $85.14 \pm$ & $518.32 \pm$ & $8,632.16 \pm$ \\
& 192.66 & 1.17 & 117.50 & $3,861.83$ \\
1.1 & $371.90 \pm$ & $86.31 \pm$ & $564.25 \pm$ & $8,979.80 \pm$ \\
& 153.22 & 1.51 & 100.25 & $4,318.80$ \\
1.2 & $335.40 \pm$ & $86.85 \pm$ & $531.80 \pm$ & $8,994.20 \pm$ \\
& 116.30 & 1,05 & 59.68 & $4,165.06$ \\
1.3 & $475.50 \pm$ & $86.46 \pm$ & $460.80 \pm$ & $7,711.30 \pm$ \\
& 187.39 & 1.71 & 94.60 & $5,815.72$ \\
1.4 & $427.00 \pm$ & $86.99 \pm$ & $545.80 \pm$ & $10,017.00 \pm$ \\
& 214.25 & 1.31 & 68.84 & $4,625.92$ \\
\hline Sig. & $\mathrm{P}=0.413$ & $\mathrm{P}=0.000$ & $\mathrm{P}=0.001$ & $\mathrm{P}=0.054$ \\
\hline
\end{tabular}

Characteristics of noise such as intensity, pulse duration and interval duration are significantly influenced by wave height ( $\mathrm{P}$-value $<0.05)$. The intensity of noise increases with increasing the wave height. Meanwhile, pulse duration and interval duration although significantly influenced by wave 
height but there is no pattern that describes the its relationship.

Other characteristics of noise (frequency) are not significantly different as the wave height increases (P-value $=0.413)$. Nevertheless, the highest frequency is generated by ocean waves with height of $1.3 \mathrm{~m}$, which is equal to $475.50 \pm 187.39$ $\mathrm{Hz}$. While the lowest frequency $335.40 \pm 116.30$ $\mathrm{Hz}$ is generated by sea waves with a height of $1.2 \mathrm{~m}$.

The strength of the wind that blows on the surface of the sea affects the sound of the waves produced. The transfer of energy from the wind to the waves occurs because of the surface stress momentum by the wind. Fluctuations in air pressure are related to the air flow above (Wicaksana, 2015). Wind speed, wind duration, fetch and direction of the wind affect the height and the period of waves generated (Hidayat, 2005). The higher of wind speed determine the increases of wave height which causes greater friction between water and air and the sound will produced. The friction causes vibrations that will disturb the balance of nearby air molecules, so that the air molecules will vibrate and produce sound (Harnapp and Noble, 1987). Wind noise and agitation/movement of the sea surface (surface waves) can produce noise with a frequency of $100 \mathrm{~Hz}-8 \mathrm{kHz}$ (Asolkar et al., 2017). Bolin and Abom (2010) state that the level of sound pressure or sound intensity increases with the increasing of wave height.

Similar to wave height, characteristics of noise waves in Cilacap waters also have values that vary based on the wave period. With a wave period ranging from $4-4.7 \mathrm{~s}$ can produce noise with a frequency of $358.50-493.20 \mathrm{~Hz}$, intensity 82.75 $86.51 \mathrm{~dB}$ re $\mu \mathrm{Pa}$, pulse duration $457.40-664.20 \mathrm{~ms}$ and interval duration of $6486.40-13621.73 \mathrm{~ms}$ (Table 2).

Characteristics of noise that are significantly affected by the wave period are pulse intensity and duration $(\mathrm{P}$-value $<0.05)$. Sound intensity decreases with the increasing wave period. Different things are shown by the duration of the pulses which have increased along with the increase in the wave period.

Other noise characteristics (frequency and interval duration) do not experience significant differences based on the wave period. The highest frequency $(493.20 \pm 186.70)$ is generated by the 4.2 second wave period and the lowest frequency $(358.50 \pm 200.05)$ is generated by the 4.7 second wave period. Meanwhile, the highest interval interval $(12,007.00 \pm 5,147.51)$ is generated by waves with a period of $4.2 \mathrm{~s}$ and the lowest
$(6,486.40 \pm 3,126.38)$ is generated by waves with a period of $4.0 \mathrm{~s}$.

Table 2. Characteristics of wave noise based on the wave period

\begin{tabular}{ccccc}
\hline $\begin{array}{c}\text { Period } \\
(\mathrm{s})\end{array}$ & $\begin{array}{c}\text { Frequency } \\
(\mathrm{Hz})\end{array}$ & $\begin{array}{c}\text { Intensity } \\
(\mathrm{dB} \text { re } \mu \mathrm{Pa})\end{array}$ & $\begin{array}{c}\text { Pulse } \\
\text { Duration } \\
(\mathrm{ms})\end{array}$ & $\begin{array}{c}\text { Interval } \\
\text { Duration } \\
(\mathrm{ms})\end{array}$ \\
\hline 4.0 & $457.80 \pm$ & $86.44 \pm$ & $457.40 \pm$ & $6,486.40 \pm$ \\
& 208.24 & 1.42 & 107.62 & $3,126,38$ \\
4.2 & $493.20 \pm$ & $86.51 \pm$ & $464.20 \pm$ & $12,007.00 \pm$ \\
& 186.70 & 2.07 & 92.34 & $5,147.51$ \\
4.3 & $422.68 \pm$ & $86.00 \pm$ & $560.40 \pm$ & $9,713.92 \pm$ \\
& 197.23 & 1.57 & 100.32 & $4,327.64$ \\
4.4 & $385.20 \pm$ & $84.58 \pm$ & $563.11 \pm$ & $8,026.09 \pm$ \\
& 155.18 & 2.85 & 142.37 & $3,892.90$ \\
4.5 & $374.73 \pm$ & $84.85 \pm$ & $573.09 \pm$ & $13,621.73 \pm$ \\
& 133.67 & 1.56 & 77.28 & $7,732.40$ \\
4.6 & $441.60 \pm$ & 84.68 & $555.40 \pm$ & $8,368.13 \pm$ \\
& 152.86 & \pm 1.67 & 84.37 & $5,820.94$ \\
4.7 & $358.50 \pm$ & $82.75 \pm$ & $664.20 \pm$ & $7,862.90 \pm$ \\
& 200.05 & 3.12 & 117.31 & $3,136.98$ \\
\hline Sig. & $\mathrm{P}=0.481$ & $\mathrm{P}=0.017$ & $\mathrm{P}=0.031$ & $\mathrm{P}=0.055$ \\
\hline
\end{tabular}

The wave period in the Cilacap Waters ranging from $4.0-4.7 \mathrm{~s}$ includes the waves that generated by the wind. This is corresponding to the expression of Triatmodjo (1999) that the wind will generate waves with a period of 0-15 s. The greater of the wave period, the more time it takes for the ocean waves to produce longer sound. Sounds that spread from the waves will be absorbed, causing the sound intensity to decrease. When sound waves propagate in water, geometric propagation occurs in all directions and attenuation where a portion of the sound energy will be absorbed by water and converted into heat (Widodo, 1989).

Characteristics of noise waves (frequency, intensity, pulse duration and duration of sound intervals) can be influenced by other factors such as wave energy. Wave energy is energy caused by the speed of water particles due to wave motion and the energy produced by the displacement of water levels due to waves (Hidayat, 2005). Sound that produced by flow processes in the surface layer of the sea, such as turbulent air flow (turbulent airflow) and surface wave motion is influenced by the equation of mass conversion and water flow momentum (Williams and Guo, 1988).

\section{Noise Characteristics of Breaking Waves}

Breaking wave in Cilacap Waters are categorized in surging types refers to the scale that used by Dackombe and Gardiner (1983) because the coefficient of breaking waves (B0) ranges from 0.013 to 0.068 . This wave type is formed because 
the site which is a breakwater which has a steep beach slope. Breakwater is a coastal building that functions as a shock wave coming. (Triatmodjo, 1999). Surging type of breaking waves occur on beaches with steep slopes such as breakwater or steep rocks where the process of breaking waves quickly (Bolin and Abom, 2010).

Surging type of breaking wave with a height of $0.5-1.0 \mathrm{~m}$ produce sounds with varying characteristics (Table 3 ). The resulting noise has a frequency of $311.10-418.40 \mathrm{~Hz}$, intensity 84.47 $89.50 \mathrm{~dB}$ re $\mu \mathrm{Pa}$, pulse duration 1,294.85 - 1597.60 $\mathrm{ms}$ and interval duration 8.879.20 - $14.463 .60 \mathrm{~ms}$.

Table 3. Characteristics of noise wave based on the breaking wave height

\begin{tabular}{|c|c|c|c|c|}
\hline $\begin{array}{l}\text { Height } \\
(\mathrm{m})\end{array}$ & $\begin{array}{c}\text { Frequency } \\
(\mathrm{Hz})\end{array}$ & $\begin{array}{l}\text { Intensity } \\
(\mathrm{dB} \text { re } \mu \mathrm{Pa})\end{array}$ & $\begin{array}{c}\text { Pulse } \\
\text { Duration } \\
(\mathrm{ms})\end{array}$ & $\begin{array}{c}\text { Interval } \\
\text { Duration } \\
(\mathrm{ms})\end{array}$ \\
\hline 0.5 & $\begin{array}{c}418.40 \pm \\
170.73\end{array}$ & $\begin{array}{c}84.47 \pm \\
1.60\end{array}$ & $\begin{array}{c}1,303.90 \pm \\
205.43\end{array}$ & $\begin{array}{c}14,463.60 \pm \\
5,682.43\end{array}$ \\
\hline 0.7 & $\begin{array}{c}311.10 \pm \\
88.31\end{array}$ & $\begin{array}{c}87.63 \pm \\
0.80\end{array}$ & $\begin{array}{c}1,597.60 \pm \\
294.42\end{array}$ & $\begin{array}{c}9,308.40 \pm \\
7,223.30\end{array}$ \\
\hline 0.8 & $\begin{array}{c}376.80 \pm \\
137.42\end{array}$ & $\begin{array}{c}88.23 \pm \\
0.88\end{array}$ & $\begin{array}{c}1,374.60 \pm \\
233.25\end{array}$ & $\begin{array}{c}8,879.20 \pm \\
4,032.67\end{array}$ \\
\hline 0.9 & $\begin{array}{c}321.00 \pm \\
129.37\end{array}$ & $\begin{array}{c}88.59 \pm \\
1.02\end{array}$ & $\begin{array}{c}1,486.65 \pm \\
268.68\end{array}$ & $\begin{array}{c}11,664.48 \pm \\
9,164.22\end{array}$ \\
\hline 1.0 & $\begin{array}{c}314.97 \pm \\
138.33\end{array}$ & $\begin{array}{c}88.97 \pm \\
1.27\end{array}$ & $\begin{array}{c}1,521.07 \pm \\
355.04\end{array}$ & $\begin{array}{c}11,114.80 \pm \\
6,711.64\end{array}$ \\
\hline 1.1 & $\begin{array}{c}403.80 \pm \\
184.51\end{array}$ & $\begin{array}{c}89.50 \pm \\
1.15\end{array}$ & $\begin{array}{c}1,294.85 \pm \\
292.42\end{array}$ & $\begin{array}{c}11,949 \cdot 35 \pm \\
8,423 \cdot 20\end{array}$ \\
\hline Sig. & $P=0.057$ & $P=0.000$ & $P=0.041$ & $P=0.378$ \\
\hline
\end{tabular}

The noise characteristics that are significantly affected by the breaking wave height are the intensity and pulse duration $(\mathrm{P}$-value $<0.05)$. Sound intensity decreases with increasing wave period. Meanwhile, although the pulse duration is significantly affected by the breaking wave height but there is no pattern of pulse duration change based on the breaking wave height.

Different from other noise characteristics, frequency and interval duration are not significantly affected by the breaking wave height. The highest and lowest noise frequencies are produced by the breaking wave heights of $0.5 \mathrm{~m}$ and $0.7 \mathrm{~m}$. While the highest and lowest duration intervals are produced by $0.5 \mathrm{~m}$ and $0.8 \mathrm{~m}$ burst wave height.

The difference in noise characteristics based on the breaking wave height is due to the unstable movement of bubbles which can affect the sound of the burst waves produced (Williams and Guo, 1988). The higher the breaking wave, the more air trapped in the breaking wave, so that more bubbles are formed (Loewen and Melville, 1991). Air trapped in breaking waves will be compressed by the weight of the water above it with a pressure greater than the pressure of the surrounding water. Excessive pressure causes the air to form bubbles and gradually rupture to produce sound (Cato and McCauley, 2002).

The intensity of the breaking wave noise tends to increase with increasing wave height. The higher the wave breaks, the greater the chance that the air trapped in the body of water will form a lot of air bubbles which will burst and cause the sound emitted to become even greater. This is in accordance with the study of Loewen and Melville (1991), that large and steep breaking waves produce a large sound also due to the amount of incoming air and bubbles that form. The sound of breaking waves is produced by individual bubbles and bubble clouds that enter during the breaking wave process (Kolaini and Crum, 1994).

Another breaking wave parameter that affects the characteristics of noise is the breaking wave velocity. The velocity of breaking wave with a range of $2.4-3.8 \mathrm{~m} / \mathrm{s}$ produces noise in frequencies $304.75-462.40 \mathrm{~Hz}$ with an intensity of 84.23 $90.00 \mathrm{~dB}$ re $\mu \mathrm{Pa}$, pulse duration 1164.40 - 1597, 60 $\mathrm{ms}$ and the interval duration $8879.20-15018.40 \mathrm{~ms}$ (Table 4).

Table 4. Characteristics of noise wave based on the breaking wave velocity

\begin{tabular}{ccccc}
\hline $\begin{array}{c}\text { Prop. } \\
\text { Velocity } \\
(\mathrm{m} / \mathrm{s})\end{array}$ & $\begin{array}{c}\text { Frequency } \\
(\mathrm{Hz})\end{array}$ & $\begin{array}{c}\text { Intensity } \\
(\mathrm{dB} r e \mu \mathrm{Pa})\end{array}$ & $\begin{array}{c}\text { Pulse } \\
\text { Duration } \\
(\mathrm{ms})\end{array}$ & $\begin{array}{c}\text { Interval } \\
\text { Duration } \\
(\mathrm{ms})\end{array}$ \\
\hline 2.4 & $374.40 \pm$ & $84.71 \pm$ & $1,337.60 \pm$ & $15,018.40 \pm$ \\
& 92.97 & 0.69 & 243.71 & $5,880.61$ \\
2.5 & $462.40 \pm$ & $84.23 \pm$ & $1,270.20 \pm$ & $13,908.80 \pm$ \\
& 228.26 & 2.27 & 180.89 & $6,107.49$ \\
3.0 & $311.10 \pm$ & $87.63 \pm$ & $1,597.60 \pm$ & $9,308.40 \pm$ \\
& 88.31 & 0.80 & 294.42 & $7,223.30$ \\
3.2 & $376.80 \pm$ & $88.23 \pm$ & $1,374.60 \pm$ & $8,879.20 \pm$ \\
& 137.42 & 0.88 & 233.25 & $4,032.67$ \\
3.3 & $304.75 \pm$ & $88.52 \pm$ & $1,465.56 \pm$ & $12,978.13 \pm$ \\
& 137.38 & 0.92 & 415.37 & $8,816.49$ \\
3.4 & $338.33 \pm$ & $88.67 \pm$ & $1,509.13 \pm$ & $9,129.93 \pm$ \\
& 122.54 & 1.15 & 316.56 & $5,092.83$ \\
3.5 & $314.97 \pm$ & $88.97 \pm$ & $1,521.07 \pm$ & $11,114.80 \pm$ \\
& 138.33 & 1.27 & 355.04 & $6,711.64$ \\
3.6 & $384.40 \pm$ & $89.38 \pm$ & $1,164.40 \pm$ & $9,340.40 \pm$ \\
& 98.77 & 1.40 & 276.57 & $10,313.97$ \\
3.7 & $416.60 \pm$ & $88.78 \pm$ & $1,323.70 \pm$ & $12,791.90 \pm$ \\
& 161.85 & 1.39 & 347.30 & $7,837.61$ \\
3.8 & $400.80 \pm$ & $90.00 \pm$ & $1,367.60 \pm$ & $12,074.40 \pm$ \\
& 253.44 & 0.81 & 168.29 & $7,133.64$ \\
\hline Sig. & $\mathrm{P}=0,177$ & $\mathrm{P}=0,000$ & $\mathrm{P}=0,154$ & $\mathrm{P}=0,408$ \\
\hline
\end{tabular}

Noise that produced by the breaking waves with a rapid seepage has a significant relationship to the noise intensity ( $\mathrm{P}$-value $<0.05)$. Noise intensity 
has increased correlated to the increasing the breaking waves velocity. Other characteristics such as frequency, pulse duration and interval duration do not change significantly as a result of the rapid change of the breaking wave velocity.

Breaking waves are one of the sources of ambient noise in the waters. The value of sound intensity from ambient noise can reach $120 \mathrm{~dB}$ re $\mu \mathrm{Pa}$ (Cato and McCaulay, 2002). The greater the higher the value and the faster the breaking wave velocity, the greater the mass of water transported (Hadi, 2011). Waves that travel to the shore carry water mass and momentum in the direction of wave propagation (Triatmodjo, 1999). Fluctuations in momentum that arise due to splashing water sprays are identified as the main cause of contributors to the sound of breaking waves (Guo, 1987).

The intensity of the breaking waves sound tends to increase along with the increase in the velocity of breaking waves. Breaking waves produce turbulence, in which air bubbles are trapped into the water (Nadaoka and Tokumi, 1991). The formation of new bubbles that enter the body of water that is turbulent by pressure fluctuations so that it emits sound waves (Klusek and Lisimenka, 2013).

The sound characteristic of breaking waves can be influenced by the distribution of surface bubbles and gas transfer during turbulent processes (Farmer and Vagle, 1989). Splashes and spray when the wave breaks is the source of sound from the breaking wave (Deane, 1997). The medium frequency range $(500-25 \mathrm{kHz}$ ) of ambient noise usually has a peak of around 300 to $500 \mathrm{~Hz}$. This is produced by the movement of the sea surface including: breaking waves, ripples, formation and bursting of bubbles (bubbles), and falling rain (Hildebrand, 2009).

\section{CONCLUSSIONS}

Wave noise has certain characteristics based on height and period of waves and breaking waves. The intensity of noise is affected by all wave parameters, while the pulse duration only changes significantly based on changes in height and wave period and the breaking wave velocity. The noise frequency is only affected by the breaking wave height. Other noise characteristics, the duration of the interval is not significantly affected by all wave parameters. The lack of diversity in the type of breaking waves causes more detailed information of the noise characteristics produced by each type of breaking wave not clearly described in this study.

\section{ACKNOWLEDGEMENTS}

Author great fully acknowledge to Directorate General of Research and Community
Services - Indonesian Ministry of Research, Technology and Higher Education (DRPM Kemristekdikti) for financial support of this research (Hibah Riset Dasar)

\section{REFRENCES}

Amron, A.L. Hanafi, I. Jaya, T. Hestirianoto, K.v. Juterzenka, 2017. Sound Characteristics of Terapon Jorbua As Representation to Its Behavior. Omni-Akuatika 13 (1): 34-42.

Amron A., I. Jaya, T. Hestirianoto, K.v. Juterzenka, 2018. Sound characteristics of Terapon fish (Terapon jorbua) as a response to temperature changes. International Journal of Environmental Science and Technology, DOI/org/10.1007/s13762018-1734-7

Asolkar, P., Das, A., Gajre, S., Joshi, Y. 2017. Comprehensive Correlation Of Ocean Ambient Noise With Sea Surface Parameters. Ocean Engineering, 138: 170-178.

Barclay, D.R., M.J. Buckingham, 2013. The depthdependence of rain noise in the Philippine Sea. J. Acoust. Soc. Am. 133 (5): 25762585

Bolin, K., and Åbom, M. 2010. Air-Borne Sound Generated By Sea Waves. J. Acoust. Soc. Am. 127(5): 2771-2779.

Cato, D.H and McCauley, R.D. 2002. Australian Research In Ambient Sea Noise. J. Acoust. Australia, 30: 1-20.

Chrismadhisti. 2014. Oseanografi Fisika. Fakultas Perikanan Dan Ilmu Kelautan: Universitas Brawijaya Malang.

Dackombe, R., and Gardiner, V. 1983. Geomorphological Field Manual. UK: George Allen \& Unwin.

Deane, G. B. 1997. Sound Generation And Air Entrainment By Breaking Waves In The Surf Zone. J. Acoust. Soc. Am. 102(5): 26712689.

Farmer, D. M., and Vagle, S. 1989. Waveguide Propagation Of Ambient Sound In The Ocean-Surface Bubble Layer. J. Acoust. Soc. Am, 86(5): 1897-1908.

Guo, Y. P. 1987. Sound Generation In The Ocean By Breaking Surface Waves. Journal of Fluid Mechanics, 181: 329-347.

Hadi, Safwan, Nining, S. N., Kandaga, P. 2005. Studi Awal Pemodelan Medan Gelombang di Laut Jawa dan Karakteristik Spektrum Energi Gelombang di Teluk Jakarta Pusat Pengembangan Kawasan Pesisir dan Laut (PPKPL), Institut Teknologi Bandung. 10(3): $169-176$. 
Harnapp, V.R. and Noble, A.G. 1987. Noise Pollution. GeoJournal, 14(2): 217-226

Hidayat, N. 2005. Kajian Hidro-Oseanografi Untuk Deteksi Proses-Proses Fisik Di Pantai. Jurnal SMARTek, 3(2): $73-85$.

Hildebrand, J.A. 2009. Anthropogenic and Naturan Source of Ambient Noise in The Ocean. Marine Ecology Progress Series, 395: 5-20.

Kaatz, I.M., 2002. Multiple sound producing mechanisms in teleost fishes and hypotheses regarding their behavioural significance. Bioacoustics 12:230-233.

Klusek, Z. and Lisimenka, A. 2013. Acoustic Noise Generation Under Plunging Breaking Waves. OCEANOLOGIA, 55(4): 809-836.

Kolaini, A. R., and Crum, L. A. 1994. Observations Of Underwater Sound From Laboratory Breaking Waves And The Implications Concerning Ambient Noise In The Ocean .J. Acoust. Soc. Am. 96(3): 1755-1766.

Lamarre, E., and Melvillea, W. K. 1994. VoidFraction Measurements And Sound-Speed Fields In Bubble Plumes Generated By Breaking Waves. J. Acoust. Soc. Am, 95(3): 1317-1328.

Loewen, M.R. and Melville, W. K. 1991. A Model Of The Sound Generated By Breaking Waves. J. Acoust. Soc. Am,90(4): 20752080.

Means, S. L., and R. M. Heitmeyer. 2001. LowFrequency Sound Generation By an Individual Open-Ocean Breaking Wave. J. Acoust. Soc. Am, 110(2): 761-769.

Medwin, H., and A. C. Daniel, Jr. 1990. Acoustical Measurements Of Bubble Production By Spilling Breakers. J. Acoust. Soc. Am, 88(1): 408-412.

Nadaoka, K. \& T. Tokumi. 1991. Sounds of Breaking Waves as a Factor Constituting Amenity in Beach Space. Coastal Engineering in Japan, 34(1): 105-116.

Peng C., X.Z. Saixi, L. Wei, S.Y. Han, C. G. Haibo, W. Tiedong, S. Guangxu, L.J. Jiang, 2016. Effects of anthropogenic sound on digging behavior, metabolism, $\mathrm{Ca} 2+/ \mathrm{Mg} 2+$ ATPase activity, and metabolism-related gene expression of the bivalve Sinonovacula constricta. Scientific Reports 6:24266.
Salinas, F. V., and A. Amezquita. 2013. Abiotic Noise, Call Frequency and Strem-Breeding Anuran Assemblages. Journal Evolutionary Ecology, 28(2) : 341-359.

Simmonds, J., D. MacLennan. 2005. Fisheries Acoustics, $2^{\text {n }} \mathrm{d}$ Edition. Blackwell Science Ltd, Oxford.UK. 472 pp.

Slabbekoorn, H., N. Bouton, I. V. Opzeeland, A. Coers, C. T. Cate, A. N. Popper. 2010. A Noisy Spring : The Impact of Globally Rising Underwater Sound Levels on Fish. Trends in Ecology and Evollution, 25 (7) : 419-427.

Southall, B. L., Bowles, A. E., Ellison, W. T., Finneran, J. J., Gentry, R. L., Greene, Jr., C. R., , Kastak, D., et al. 2007. Marine mammal noise exposure criteria: Initial scientific recommendations. Aquatic Mammals, 33: 411-521.

Triatmodjo, B. 1999. Teknik Pantai. Beta Offset. Yogyakarta. 397 hal.

Triwahyanti L., A.S. Cyndana Y.H. Sefnianti, R.J. Sari, A. Amron, 2018. Transmission loss estimation of underwater sound based on the noise intensity emmited by MV. Pengayoman IV in Tanjung Intan cruise line, Cilacap. E3S Web of Conferences 47, 04011

Umpel, I. F., J. D. Mamoto, M. I. Jasin. 2015. Studi Karakteristik Gelombang pada Daerah Pantai Matani Satu. Jurnal Sipil Statik,3(9): 651-661.

Wakkary, A. C., Jasin, M. I., Dundu, A.K.T. 2017. Studi Karakteristik Gelombang Pada Daerah Pantai Desa Kalinaung Kab. Minahasa Utara. J.Sipil Statik, 5(3): 167-174.

Wicaksana, S., I. Sofian, W. Pranowo, A. R. T. D. Kuswardani, Saroso, dan N. B. Sukoco. 2015. Karakteristik Gelombang Signifikan Di Selat Karimata Dan Laut Jawa Berdasarkan Rerata Angin 9 Tahunan (2005-2013). J.OmniAkuatika, 11(2): 33-40.

Widodo,J. 1989. Prinsip Dasar Hidroakustik Perikanan. J. Oseana, 14(3): $81-92$.

Williams, J. F., and Guo, Y. P. 1988. Mechanisms of Sound Generation at The Ocean Surface. Sea Surface Sound Dordrecht : 309-324 